\title{
Histopathological Characteristics may not be Useful in the Differential Diagnosis between Basal Cell Carcinoma and Benign Tumors of Cutaneous Appandages Originating from Hair Follicle
}

\author{
Ilker SENGUL ${ }^{1}$, Demet SENGUL ${ }^{2}$, Muzeyyen H. ASTARCI ${ }^{3}$, Huseyin USTUN³ \\ ${ }^{1}$ Giresun University Faculty of Medicine, Department of General Surgery, Giresun \\ ${ }^{2}$ Prof. Dr. A. Ilhan Ozdemir State Hospital, Department of Pathology, Giresun \\ ${ }^{3}$ Ankara Training and Research Hospital, Department of Pathology, Ankara, TURKEY
}

\begin{abstract}
Differential diagnosis between benign tumors of cutaneous appandages originating from hair follicle (BTCOHF) (trichoadenoma [TA], trichofolliculoma [TF], trichoepithelioma [TE] and trichoblastoma [TB]) and basal cell carcinoma (BCC) have been tedious for the pathologists, especially in the presence of small specimens to date. Thirty cases of BTCOHF and 30 cases of BCC were retrieved from the archives, deposited from 2004 to 2008. Age, sex, localisation and histopathological characters such as ulceration, pigmentation, inflammation, and cyst formation were comparatively evaluated between both groups and each subgroups. No significant diference was detetected between two groups in the rate of the age, sex and the histopathology. Besides, histopathological characters were not significant for the subgroups of BCC. However, ulceration was observed in TE (Of 21 cases 5, [23.8\%]) and TB (All the 5 cases, [100\%]), but not in TA and TF which are the subgroups of BTCOHF and the difference was significant $(p=0,005)$. But, pigmentation, inflammation and cyst formation were not significant among the subgroups of both groups. We can conclude that BCC and BTCOHF may not be discriminated concerning age, sex and histopathological characters including ulceration, pigmentation, inflammation, and cyst formation. Secondly, one may not make the differential diagnosis easily even between the subgroups of each group via evaluating the histopathological characters, so that might create some life-threatening unwelcome outcomes.
\end{abstract}

Keywords: Basal cell carcinoma, Pigmentation, Inflammation, Histopathology

\section{ÖZET}

Histopatolojik karakterler Bazal Hücreli Karsinoma ile Kıl Follikülünden Köken Alan Benign Deri Eki Tümörlerinin Ayırıcı Tanısında Yararı Olamayabilir

Trikoadenoma, trikofolliküloma, trikoepitelyoma ve trikoblastomanın bazal hücreli karsinomadan ayıııı tanısı, bugüne kadar özellikle küçük spesimenlerde patologlar için can sıkıcı ve usandırıcı olmaya devam edegelmiştir. Otuz kll follikülünden köken alan benign deri eki tümörleri olgusu ve 30 bazal hücreli karsinoma olgusu, 2004 - 2008 yılları arasında depolandığı arşivden yeniden edinildi. Yaş, cinsiyet, lokalizasyon ve ülserasyon, pigmentasyon, inflamasyon ve kist formasyonu gibi histopatolojik karekterler her iki grup ve her subgrup arasında karşılaşıımalı olarak değerlendirildi. Yaş, cinsiyet, lokalizasyon ve histopatoloji açısından iki grup arasında anlamIı fark saptanmadı. Ayrıca, histopatolojik karekterler bazal hücreli karsinomanın subgrupları için anlamlı değildi. Bununla birlikte; ülserasyon, kll follikülünden köken alan benign deri eki tümörlerinin subgrupları olan trikoepitelyoma (21 olgunun 5'inde [\%23.8]) ve trikoblastomada (5 olgunun tümünde [\%100]) izlendi, ancak trikoadenoma ve trikofollikülomada izlenmedi ve bu fark anlamI bulundu ( $\mathrm{p}=0.005)$. Pigmentasyon, inflamasyon ve kist formasyonu her iki grubun subgrupları arasında anlamlı değildi. 
Sonuçta şunu söyleyebiliriz ki, bazal hücreli karsinoma ve kıl follikülünden köken alan benign deri eki tümörlerinin; yaş, cinsiyet ve ülserasyon, pigmentasyon, inflamasyon ve kist formasyonu gibi histopatolojik karekterlere göre ayırt edilemeyebilir. İkinci olrak; histopatolojik karekterlerin değerlendirilmesi yoluyla, anılan her iki grubun, subgrupları arasında bile kolaylıkla ayrım yapılamayabilir ve dolayısıyla bu da yaşamı tehdit edici sıkıntılar yaratabilir.

Anahtar Kelimeler: Bazal hücreli kanser, Pigmentasyon, Enflamasyon, Histopatoloji

\section{INTRODUCTION}

Benign tumors of cutaneous appandages originating from hair follicle (BTCOHF) are firstly classified by Headington in 1976 as germ layer hamartomas of hair follicle, tumors of hair follicle originated from germ layer, tumors originated from external layer of hair follicle (Trichilemmoma) and tumors originated from prefollicular mesenchyme. ${ }^{1}$ Afterwards, Mehregan $^{2}$ divided them in 1985 by simplifying to three subgroups which are called hyperplasia, adenoma and epithelioma. Ackerman et al criticised the classifications, used in eight textbooks of dermatopathology in 2001.,4 Tumors of cutaneous appandages originating from hair follicle was seperated into two main subgroups as benign tumors and malignant tumors according to 2003 Classification of World Health Organization (WHO). ${ }^{1}$

Trichoadenoma (TA) is firstly determined by Nikolowski ${ }^{5}$ in 1958 and is a rare tumor which is usually seen as a nodular lesion on the face and buttocks. ${ }^{6,7}$ Trichofolliculoma (TF) is follicularly differentiated hamartomas mostly appearing during adulthood ${ }^{8}$ without sex special tendency. ${ }^{2,9}$ Although TF is a benign tumor, Stern et al reported the perineural invasion of it. ${ }^{10}$ Trichoepithelioma (TE) is a benign, cutaneous mesenchymal tumor originating from germ layer of hair follicle. ${ }^{11-13}$ Trichoblastoma (TB) is extremely rare benign tumors located deep dermis and subcutis. ${ }^{14}$ It is frequently seen on head and neck ${ }^{3,15}$ and mostly sized less than $1 \mathrm{~cm}$ in diameter. ${ }^{2}$ Although all they are benign, their aggressive forms resemble basal cell carcinoma $(\mathrm{BCC})^{11}$ and potentially tend to metastasize. ${ }^{16-18}$

$\mathrm{BCC}$ is the most common malignancy worldwide in white people ${ }^{19}$ and accounts for $65-75 \%$ of all skin tumors..$^{20}$ It originates from pluripotential primordial germ cells and founds in basal layer of epidermis and cutaneous appandages resembling the structure of hair follicle morphologically. ${ }^{21}$ It has been shown by using immunhistochemical methods that keratinous pattern of BCC resembles external stem sheath of hair follicle rather than epidermis. It has given rise to thought that the tumor may have the follicular origin to date. ${ }^{21,22}$ Although having red or blond hair, green or blue eyes phenotypically and having a tan difficultly are some kinds of risks for $\mathrm{BCC}^{23,24}$; the most important exogen factor is being exposed to ultraviolet radiation. ${ }^{21,23-27}$ Additionally, it is believed that ultraviolet (UV) B radiation (290-320 nm, wavelength) is more effective than UVA radiation (320 $400 \mathrm{~nm}$, wavelength). ${ }^{21}$

Differential diagnosis between BTCOHF (TA, TF, $\mathrm{TE}$ and TB) and BCC may be troublesome for pathologists, especially in the presence of small specimens. TE and TB are tumors of cutaneous appandages which include well circumscribed islands constructed by basal cells in the dermis and having pallisading cells peripherally. It contains papillary mesenchymal bodies differentiated from abortive hair papilla formation which may be confused with BCC. There are more mitoses and apoptotic cell necrosis in BCC than both TE and TB. ${ }^{23}$

BTCOHF may be treated by "shave biopsy" or cura$\operatorname{tage}^{28}$, but BCC is a low grade malignant tumor. ${ }^{29} \mathrm{It}$ rarely metastasizes having the incidence of $0.0028 \%$ $-0.55 \% .^{25,30}$ Its recurrence for 5-year survival is $5 \%{ }^{30}$ and may show local invasion, especially in the types of infiltrative and morpheic. ${ }^{31}$ Thus, it requires total excision and follow up. ${ }^{28}$ Although some histolopathological characters may contribute to make the differential diagnosis of BTCOHF and BCC, it may be very difficult for pathologists, particularly in small biopsy specimens. Therefore, immunhistochemical tecniques can be beneficial to diagnose accurately. ${ }^{32}$

In the current study, we investigated the age, sex, localisation, histopathological characters consisting ulceration, pigmentation, inflammation, and cyst formation seperately among each subgroups and comparetively between the groups of BTCOHF and BCC to make the distinct differential diagnosis. 


\section{MATERIALS AND METHODS}

The investigation conforms to the principles outlined in the appropriate version of 1964 Declaration of Helsinki and approval of the present study was received by The Ethics Committee of Ankara Education and Research Hospital.

A total of 30 cases of BTCOHF ( 21 cases of TE [Group 1a], 70\%; 5 cases of TB [Group 1b], 16.6\%; 2 cases of TA [Group 1c], 6.7\%; 2 cases of TF [Group 1d], 6.7\%) and 30 cases of BCC were retrieved and analysed from the archives of Department of Pathology, Ankara Education and Research Hospital. The cases of BTCOHF had been deposited between 2004 and 2008 and the cases of BCC had been deposited during the year of 2008. The punch biopsies and the incisional biopsies not enclosing the neighboring epidermis and dermis were not included in the study.

Former H\&E sections of all the cases were reexamined under light microscope for the histological classification which was created on the basis of the growing pattern. The cases of BCC were classified as noduler [18 cases, Group 2a, 60\%], superficial [4 cases, Group 2b, $13.3 \%$ ], infiltrative [2 cases, Group 2c, 6.7\%], and mixed [6 cases, Group 2d, 20\%] containing two or more types together. The age, sex, ulceration, localisation, pigmentation, inflammation, and cyst formation were comparatively evaluated between both groups of BTCOHF and BCC totally and between each subgroups which belong to the same main group.

A pair of $4 \mu \mathrm{m}$ sections of formalin-fixed (10\% solution; PH 7.0 - 7.6), parafin-embedded tissues were prepared and placed on the slides which were covered by poly-L lysine for each case. The original H\&E stained slides were detained for the comparision with immunostained sections.

Statistical Analysis: All the specimens were observed under a light microscope. For the statistical analysis SPSS - 13.0, a statistical programme based on computer was used. All datas were expressed as means \pm standard errors of means (SEM). In the analysis of numerical variants Student $\mathrm{T}$ test, for comparing rational datas Pearson chi-square and Fisher's Exact tests were utilized at suitable areas. Pearson correlation analysis was managed for the relationship between the numerical datas and $\mathrm{p}$ - value less than 0.05 was considered as significant for all the tests.

\section{RESULTS}

\section{Age, Sex, and Localization}

While patients with BTCOHF (14 females and 16 males) were ranged in age from 26 to 74 years (Median, 61.43 \pm 14.43 ), patients with BCC (12 females and 18 males) were ranged in age from 34 to 85 years (Median, 64.60 \pm 10.89 ) and the difference between both groups was not significant (Table 1).

While both tumor groups were localised at on the head region, BTCOHFs were mostly detected on the nasal area and BCCs were mostly determined on the eye circumference (Table 2, 3).

\section{Ulceration, Pigmentation, Inflammation and Cyst Formation}

Ulceration, pigmentation, inflammation and cyst formation were examined on the original H\&E stained slides. While 10 of BTCOHF (33.3\%) had ulceration, 20 of them (66.7\%) not. Thirteen of BCC (56.7\%) had ulceration (Figure 1), but 17 of them $(43.3 \%)$ not and there was no significant diference between BTCOHF and BCC on the basis of existance of ulceration $(p=0.426)$. Pigmentation was observed in 3 of BTCOHF (10\%), but 27 of them (90\%) not. Meanwhile 9 of BCC (30\%) had pigmentation (Figure 2), but 21 of them (70\%) not. No significant diference detected between two groups taking into account of being of pigmentation $(\mathrm{p}=0.053)$. Inflammation was observed in 3 of BTCOHF (10\%), but 27 of them (90\%) not. However, 12 of BCC (40\%) had inflammation, but 18 of them $(60 \%)$ not. There was no significant diference between the groups regarding presence of inflammation $(\mathrm{p}=0.007)$. Cyst formation was seen in 11 of BTCOHF (36.7 \%) (Figure 3), but 19 of them (63.3\%) not. Fifteen of BCC (50\%) had cyst formation (Figure 4), but 15 of them $(50 \%)$ not. There was no significant diference between two groups considering of presence of cyst formation $(\mathrm{p}=0.297)$ (Table 4).

The histopathology of BTCOHF and BCC are summarized in Table 5 and Table 6 . There was no significant diference between the subgroups of BCC (Table 6). Besides, ulceration was observed in TE and $\mathrm{TB}$, but not in TA and TF and it was significant $(\mathrm{p}=$ $0.005)$. 
Table 1. The mean of age and sex of both groups

\begin{tabular}{|llll|}
\hline & BCC (n:30) & BTCHOF (n:30) & p \\
\hline AGE & $64.60 \pm 10.89$ & $61.43 \pm 14.43$ & 0.342 \\
SEX & & & \\
Female & $12(40 \%)$ & $16(53.3 \%)$ & 0.602 \\
Male & $18(60 \%)$ & $14(46.7 \%)$ & \\
\hline
\end{tabular}

\section{DISCUSSION}

Because of BTCOHF and BCC resemble extremely similar histopathological features, differentiation between them particularly in the small and superficial biopsies is persisting to be an important diagnostic challenge. Besides this, their treatment and prognosis are dissimilar. So, a large number of various contributory laboratory techniques have been researched on the purpose of making that definitive diagnosis.

BCC occurs 95\% between the ages of $40-79$ and meanly at the age of $62 .{ }^{33}$ Our study was supporting it that patients with $\mathrm{BCC}$ were ranged from 34 to 85 years with the median of $64.60 \pm 10.89$ in age. The median age of the patients with BTCOHF was 61.43 \pm 14.43 and it was similiar with the literature. The

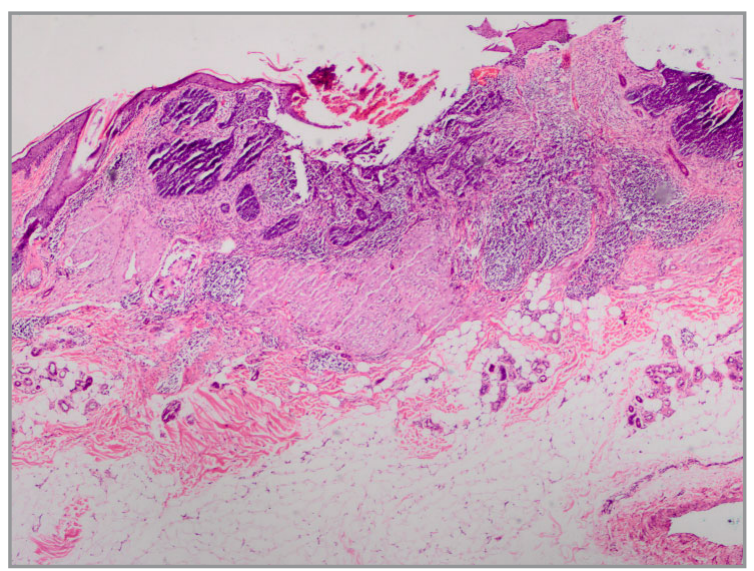

Figure 1. Lymphocystic infiltrations in the periphery of tumor islands and the superficial ulcerations (BCC, Original magnification, H\&E, 5×10) .

difference between two groups was not significant statistically. As well as BCC is more frequently seen in man; there is an increase in the incidance in woman, recently. When there is no gender difference among the Italian and Australian patients, it is mostly observed in woman in Far Eastern countries and in Turkey. ${ }^{33}$ Contrarily, in the present study, BCC was including 18 man (60\%), 12 woman (40\%) and BTCOHF was containing 16 man (53.3\%), 14 woman $(46.7 \%)$. The difference between two groups was not significant.

Table 2. Localisations for the group of BTCHOF

\begin{tabular}{|lllllllllll|}
\hline & Fore-head & Nose & Eye-brow & Periorbital & Nazolabial & Back & Preauricular & Scalp & Lip & Cheek \\
\hline TE & 1 & 5 & 2 & 3 & 5 & 2 & 0 & 2 & 1 & 0 \\
TB & 0 & 1 & 1 & 0 & 0 & 0 & 1 & 1 & 0 & 1 \\
TA & 0 & 1 & 0 & 1 & 0 & 0 & 0 & 0 & 0 & 0 \\
TF & 0 & 1 & 0 & 1 & 0 & 0 & 0 & 0 & 0 & 0 \\
\hline
\end{tabular}

Table 3. Localisations for the group of BCC

\begin{tabular}{|lllllllllll|}
\hline & Fore-head & Nose & \multicolumn{2}{l}{ Eye-brow } & Peri-orbital & Nazolabial & Back & Preauricular Scalp & Lip & Cheek \\
\hline Noduler & 2 & 3 & 2 & 4 & 1 & 0 & 0 & 3 & 1 & 2 \\
Superficial & 1 & 1 & 0 & 0 & 0 & 1 & 0 & 1 & 0 & 0 \\
Infiltrative & 0 & 0 & 0 & 0 & 0 & 0 & 1 & 0 & 0 & 1 \\
Mixed & 1 & 0 & 0 & 4 & 0 & 0 & 0 & 0 & 1 & 0 \\
\hline
\end{tabular}




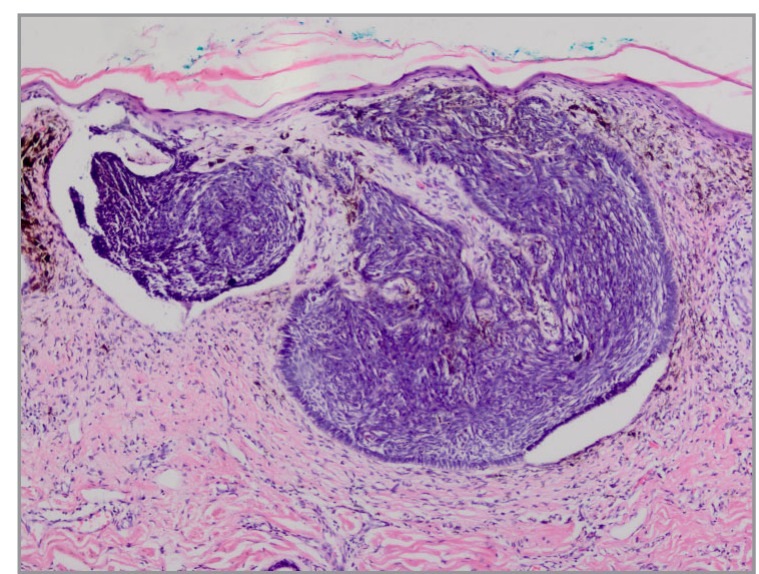

Figure 2. Pigmentations in tumor islands and the periphery of which (BCC, Original magnification, H\&E, 5×10).

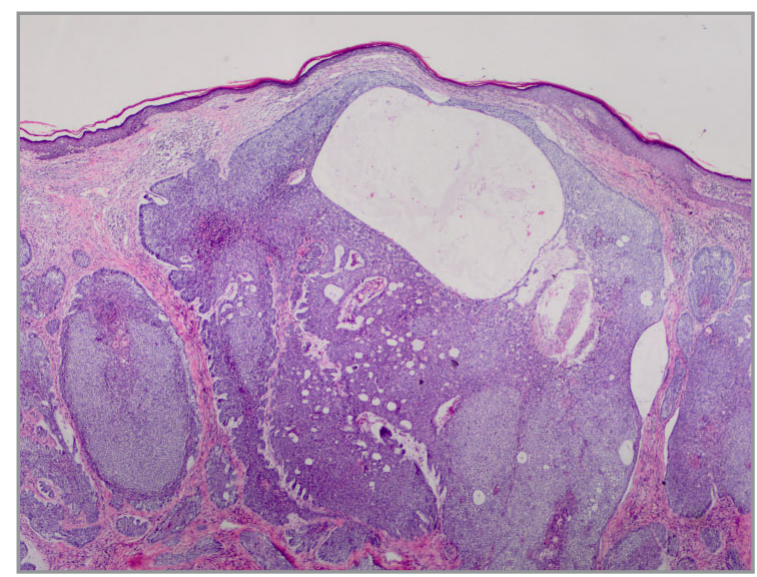

Figure 4. Cyst formations in the centers of tumor islands (BCC, Original magnification, H\&E, 5×10).

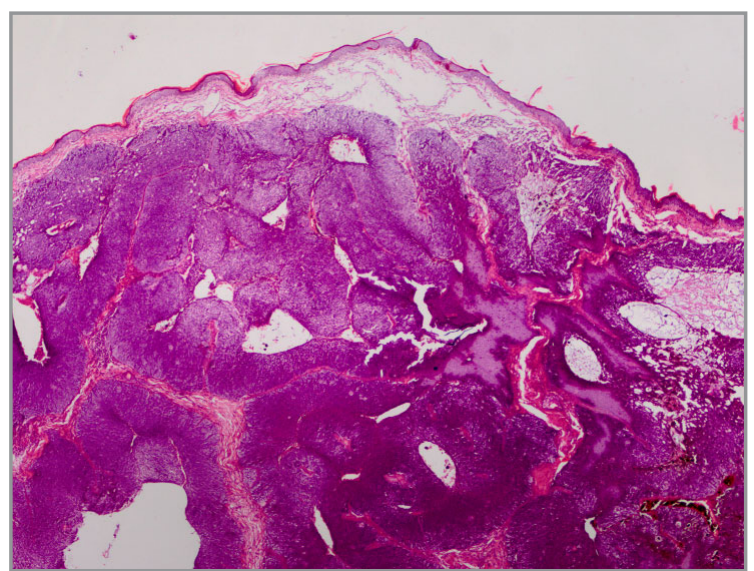

Figure 3. Cyst formations in the centers of tumor islands and pigmentations among the tumor islands (TB, Original magnification, H\&E, 5×10).

BCC is mostly (85\%) seen in areas which are exposed to sun, namely head and neck region, particularly on the nose. The forehead, periocular areas, chin, and ears are also risky body portions for $\mathrm{BCC} .^{34} \mathrm{BTCO}-$ $\mathrm{HF}$ is mostly observed on the head and neck region (TE-nasolabial sulcus, TA \& TF-face, TB-scalp). ${ }^{3}$ The current study was in a supporting manner that, both groups was on the head and neck region. While $\mathrm{BCC}$ was most frequently on the periocular areas, BTCOHF was on the nose.

In the present study, we also evaluated the histopathology of both groups and the subgroups of them for making the differential diagnosis. We did not determined any significant difference between both groups and subgroups of them regarding that. Ulcerati-

Table 4. The comparision of ulceration, pigmentation, inflammation and cyst formation for both groups

\begin{tabular}{|c|c|c|c|c|}
\hline & & BCC $(n=30)$ & BTCHOF $(n=30)$ & $\mathbf{p}$ \\
\hline \multirow[t]{2}{*}{ ULCERATION } & Yes & $13(\% 56.7)$ & 10 (\% 33.3) & \\
\hline & No & $17(\%$ 43.3) & $20(\%$ 66.7) & 0.426 \\
\hline \multirow[t]{2}{*}{ PIGMENTATION } & Yes & 9 (\% 30) & $3 \quad(\% 10)$ & \\
\hline & No & $21(\% 70)$ & 27 (\% 90) & 0.053 \\
\hline \multirow[t]{2}{*}{ INFLAMMATION } & Yes & $12(\% 40)$ & $3 \quad(\% 10)$ & \\
\hline & No & $18(\%$ 60) & 27 (\% 90) & 0.007 \\
\hline \multirow[t]{2}{*}{ CYST FORMATION } & Yes & $15(\%$ 50) & $11(\% 36.7)$ & \\
\hline & No & 15 (\% 50) & 19 (\% 63.3) & 0.297 \\
\hline
\end{tabular}




\begin{tabular}{|c|c|c|c|c|c|c|}
\hline & & TE (n: 21) & TB (n: 5) & TA (n: 2) & TF (n: 2) & p \\
\hline \multirow[t]{2}{*}{ ULCERATION } & Yes & 5 (\%23.8) & $5(\% 100)$ & - & - & 0.005 \\
\hline & No & $16(\% 76.2)$ & - & $2(\% 100)$ & $2(\% 100)$ & \\
\hline \multirow[t]{2}{*}{ PIGMENTATION } & Yes & 3 (\%14.3) & - & - & - & 0.699 \\
\hline & No & $18(\% 85.7)$ & $5(\% 100)$ & $2(\% 100)$ & $2(\% 100)$ & \\
\hline \multirow[t]{2}{*}{ INFLAMMATION } & Yes & 2 (\%9.5) & $1(\% 20)$ & - & - & 0.800 \\
\hline & No & $19(\% 90.5)$ & $4(\% 80)$ & $2(\% 100)$ & $2(\% 100)$ & \\
\hline \multirow[t]{2}{*}{ CYST FORMATION } & Yes & 9 (\%42.9) & $2(\% 40)$ & - & - & 0.443 \\
\hline & No & $12(\% 57.1)$ & 3 (\%60) & 2 (\%100) & $2(\% 100)$ & \\
\hline
\end{tabular}

on was significantly observed in TE and TB, but not in TF. However, a significant difference did not assign between both groups. Inflammation was significantly observed more densely in BCC then BTCO$\mathrm{HF}$, but no difference was detected among the subgroups.

In conclusion, we determined in this study that there was no difference between BCC and BTCOHF regarding the age, sex and histopathological characters including ulceration, pigmentation, inflammation and cyst formation. Hence, notably in small specimens, one may not differ BCC from BTCOHF by using the parameters of age, sex and histopathology. That troublesome might lead to some life-threatening undesirable results. However, we would like to emphasize that the limited number of the cases was the handycap of our study. Notwithstanding, varied mar- kers, dissimiliar techniques, and larger series are necessary for the precise discriminations.

\section{ACKNOWLEDGEMENTS}

We would like to deeply thank our personel of The Pathology Laboratory of Department of Pathology, Ankara Education and Research Hospital, named Sefika Mercan, Kadriye Aglamaz, Hamdi Aydin, Haydar Kayabas and the others for providing us with useful and selfless assistance.

\section{REFERENCES}

1. Cotton D. Trouble some tumours 1: Adnexal tumours of the skin. J Clin Pathol 44: 543-548, 1991.

\begin{tabular}{|c|c|c|c|c|c|c|}
\hline & & Noduler (n: 18) & Superficial (n: 4) & Infiltrative (n: 2) & $\operatorname{Mixed}(n: 6)$ & $\mathbf{p}$ \\
\hline \multirow[t]{2}{*}{ ULCERATION } & Yes & 6 (\%33.3) & $2(\% 50)$ & $1(\% 50)$ & $4(\% 66.7)$ & \\
\hline & No & $12(\% 66.7)$ & $2(\% 50)$ & $1(\% 50)$ & 2 (\%33.3) & 0.537 \\
\hline \multirow[t]{2}{*}{ PIGMENTATION } & Yes & $4(\% 22.2)$ & $3(\% 75)$ & $1(\% 50)$ & $1(\% 16.7)$ & \\
\hline & No & $14(\% 77.8)$ & $1(\% 25)$ & $1(\% 50)$ & 2 (\%83.3) & 0.153 \\
\hline \multirow[t]{2}{*}{ INFLAMMATION } & Yes & 6 (\%33.3) & $2(\% 50)$ & $1(\% 50)$ & $3(\% 50)$ & \\
\hline & No & $12(\% 66.7)$ & $2(\% 50)$ & $1(\% 50)$ & $3(\% 50)$ & 0.841 \\
\hline \multirow[t]{2}{*}{ CYST FORMATION } & Yes & $11(\% 61.1)$ & - & - & $4(\% 66.7)$ & \\
\hline & No & 7 (\%38.9) & $4(\% 100)$ & $2(100)$ & 2 (\%33.3) & 0.056 \\
\hline
\end{tabular}


2. Mehregan $\mathrm{AH}$. Hair follicle tumors of the skin. J Cutan Pathol 12: 189-195, 1985.

3. Weedon D, Strutton G. Tumors of cutaneous appendages. In Skin Pathology. 2nd edition. New York, Churchill-Livingstone, 2002: 859-901.

4. Ackerman AB, Reddy VB, Soyer HP. Neoplasms with follicular differentiation. 2nd edition. New York, Ardor Scribendi Publisher, 2000.

5. Nikolowski W. Trichoadenoma (organoid follicular hamartoma) Arch Clin Exp Dermatol 207: 34-45, 1958.

6. Rahbari $\mathrm{H}$, Mehragan A, Pinkus $\mathrm{H}$. Trichoadenoma of Nikolowski. J Cutan Pathol 4: 90-98, 1977.

7. Swaroop DS, Ramakrishna BA, Bai SJ, Shanthi V. Trichoadenoma of Nikolowski. Indian J Pathol Microbiol 51: 277-279, 2008.

8. Choi EH, Ahn SK. Hair follicule nevus. Int J Dermatol 31: 578-581, 1992.

9. Gray HR, Helwing HB. Trichofolliculoma. Arch Dermatol 86: 619-625, 1962

10. Stern JB. Trichofolliculoma showing perineural invasion trichofolliculocarcinoma? Arch Dermatol 115: 1003-1004, 1979.

11. Headington JT. Tumors of the hair follicle. Am J Pathol 85: 480-505, 1976.

12. Yamamoto O, Asahi M. CK expression in trichoblastic fibroma, trichoepitelioma and basal cell. Br J Dematol 140: 8-16, 1999.

13. Gray HR, Helwing HB. Epitelioma adenoides cysticum and solitary trichoepitelioma. Arch Dermatol 87: 102114, 1963.

14. Kaddu S, Schaeppi H, Kerl H, Soyer HP. Subcutaneous trichoblastoma. J Cutan Pathol 26: 490-496, 1999.

15. Reguena L, Barat A. Giant trichoblastoma of the scalp. Am J Dermatopathol 15: 497-502, 1993.

16. Alsaad KO, Obaidat NA, Ghazarian D. Skin adnexal neoplasms-part 1: An approach to tumours of the pilosebaceous unit. J Clin Pathol 60: 129-144, 2007.

17. Schulz T, Proske S, Hartschuh W, et al. High-grade trichoblastic carcinoma arising in trichoblastoma: a rare adnexal neoplasm often showing metastatic spread. Am J Dermatopathol 27: 9-16, 2005.

18. Schulz T. High-grade trichoblastic carcinoma. Am J Dermatopathol 27: 9-16, 2005.

19. Miller SJ. Aethiology and pathogenesis of basal cell carcinoma. Clin Dermatol 13: 527-536, 1995.

20. Ionescu DN, Arida M, Jukic DM. Metastatic basal cell carcinoma. Four case reports, review of literature and immunohistochemical evalution. Arch Pathol Lab Medicine 130: 45-51, 2006.

21. Roewert-Huber JJ, Lange-Asschenfeldt B, Stockfleth $\mathrm{E}, \mathrm{Kerl} \mathrm{H}$. Epidemiology and aetiology of basal cell carcinoma. Br J Dermatol 157: 47-51, 2007.

22. Leffel DJ, Fitzgeral DA. Basal cell carcinoma. Fitzpatrick's Dermatology in General Medicine. 5th edition. New York, McGraw Hill 1999: 857-864.
23. Crowson AN. Basal cell carcinoma: Biology, morphology and clinical implications. Mod Pathol 19 Suppl 2:S127-47, 2006.

24. Wong CSM, Strange RC, Lear JT. Basal cell carcinoma: Clinical Review. BMJ 327: 794-798, 2003.

25. Lear JT, Harvey I, deBerker D, et al. Basal cell carcinoma. J R Soc Med 91: 585-588, 1998.

26. Bastiaens MT, Hoefnagel JJ, Bruijn JA, et al. Differences in age, site distribution and sex between nodular and superficial basal cell carcinomas indicate different types. J Invest Dermatol 110: 880-884, 1998.

27. Gallagher RP, Hill GB, Bodjik CD, et al. Sunlight exposure pigmentary factors and risk of nonmelanocytic skin cancer. I. Basal cell carcinoma. Arch Dermatol 131: 157-163, 1995.

28. Pham TT. CD10 Expression in trichoepitelioma and basal cell carcinoma. J Cutan Pathol 33:123-8, 2006.

29. Murphy GF, Elder DE. Atlas of Tumour Patholog: Nonmelanocytic tumours of the skin third series. 3rd edition. Washington, DC, Armed Forced Institute of Pathology (AFIP) 1991: 47-60.

30. Brenn T Mc Kee PH. Tumors of the surface epithelium. In: Patholoy of the skin with clinical correlations. 3rd edition. Philadelphia, Elsevier Mosby, 2005: 11671184.

31. Saldanha G, Fletcher A, Slater DN. Basal cell carcinoma: A dermatopathological and molecular biological update. Br J Dermatol 148: 195-202, 2003.

32. Kirchmann T, Prieto VG, Smoller BR. CD34 staining pattern distinguishes basal cell carcinoma from trichoepitelioma. Arch Dermatol 130: 589-592, 1994.

33. Tiftikcioglu YO, Karaaslan O, Aksoy HM, et al. Basal cell carcinoma in Turkey. J Dermatol 2: 91-95, 2006.

34. Odom RB, James WD, Berger TG. Andrew's diseases of the skin clinical dermatology. 9th edition. Philadelphia, WB Saunders, 2000: 816-817.

\section{Correspondence}

Dr. Illker ŞENGÜL

Giresun Üniversitesi Tıp Fakültesi

Genel Cerrahi Anabilim Dalı

Nizamiye Yerleşkesi

28100 GIRESUN / TURKEY

Tel: (+90.454) 2140369

Fax: (+90.454) 2140247

e-mail: dr.ilker52@mynet.com ilker.sengul@giresun.edu.tr 